\title{
10 \\ Claiming Pule, Manifesting Mana: Ordinary Ethics and Pentecostal Self-making in Samoa
}

\author{
Jessica Hardin
}

Mid-week at a week-long revival at an Assemblies of God Church in a village near Apia, Pastor Keni began his sermon by saying, 'When you fellowship with God, he pours His spirit and pulea [governs] the people who believe in God. This will begin the spiritual life and the righteous life'. The relationship, he explained, 'is warm and close, and He moves'. Especially when 'you pray and fast, He keeps you warm and will do things for His people'. He continued, 'we have this revival to ask the mana [power] to come down and to renew our life. We sing in the mana. We dance in the mana.' He finished by saying 'remember our church is a Pentecostal church. A Pentecostal church is full of the mana of the Holy Spirit, where we see the signs of the mana, where we see the miracles of the church, where we see changes in lives, where we see love and togetherness from God'. This revival sermon aimed to teach congregants how to bring the pule (authority) of God into the world and the blessings of God into individual lives through the bestowal of mana. The congregants were told that through faith and a personal relationship with God, divine pule is brought into being. They must pray and fast to bring about this relationship as a way to bring mana into their lives. Through celebrating, witnessing and manifesting mana, individual lives as well as communities would change. 
Mana is defined in Samoan as divine power or God's grace (Anae 1998; Schoeffel personal communication, 2 November 2015). The Samoan definition resonates with Hawaiian definitions of mana as 'power originating from a spiritual source' (Silva 1997: 91) and the Māori notion of mana defined as 'power, prestige, authority, control, "psychic force," spiritual power, charisma' (Salesa 2011: ix). Wende Elizabeth Marshall, also writing of Hawai'i, suggests that mana is 'more than a theory, mana is a relationship and a practice that in precolonial times was the source of health, vitality and abundance, in which a thriving world was the co-creation of divinity, humanity, and nature: fractal and indivisible' (Marshall 2012: 88). Most broadly, mana 'is an indigenous ontology' (Marshall 2012: 88; see also Kame'eleihiwa 1992; Shore 1989; Valeri 1985) and 'a pan-Polynesian concept of divinely sanctioned power and efficacy' (Henderson 2010: 310); it is spiritual power and prestige (Tengan, Ka'ili and Fonoti 2010) and spiritual authority and sovereignty (Meleisea 1997: 469). In this chapter, I examine the related meanings and uses of pule and mana, which, when invoked together, help to configure each other. ${ }^{1}$ The relational invocation of pule and mana is a strategic, yet ordinary, everyday ethical practice for Pentecostal Christians.

While mana and pule are concepts shared among Christians in Samoa, I focus on two everyday uses of the terms: first, how Pentecostal Christians are taught to manifest mana, which is a capacity that is supposed to be available to all born-again believers; second, how mana and pule are invoked in interdenominational contexts. Claiming pule and channelling mana mediates tensions surrounding Pentecostal Christians striving for individual agency and indigenous notions of flexible and context-specific notions of agency, which are also expressed in mainline Christianity. Pentecostal Christians are explicitly taught how to manage individual agency in ethical ways through cultivating a personal relationship with God, which enables supplicants to become agents of mana. Claiming pule and channelling

1 Others have also argued that mana is relational with other terms such as tapu (Samoan) and sau (Fijian). Bradd Shore argues that tapu 'point[s] to alternative conditions of mana' (Shore 1989: 148). Tapu, according to Shore, is 'symbolically formalized and thereby focused mana' (1989: 150); it implies potency, respect, and danger. Tapu 'represents generative power (mana) in its contained form' (Shore 1989: 149). Tapu thus refers to the productive containment of mana in the bodies of matai (titled chiefs). Matt Tomlinson (2006; see also Tomlinson and Bigitibau, this volume) argues that sau (spiritual power) is a term used in parallel to mana (efficacy) in Fijian discourse. 
mana are thus discursive tools for managing tensions surrounding agency by allowing born-again Christians to de-centre individual agency and foreground God's agency. In everyday life in Samoa there is a hierarchical imperative of defaulting to titled or high status people. The three most widely circulating criticisms in Samoa-fiapalagi (to try or want to be white), fiapotu (to try or want to be smart), and accusations that suggest pride, including fiamaualuga (wanting to be high) or mimita (to be boastful) - suggest that claiming authority and power is difficult because of a general bias against individual agency and non-titled authority (see also Gershon 2006: 145). The personal and individual relationship with God encouraged in Pentecostal Christianity heightens these already present anxieties about individual agency and authority (see also Eriksen 2014).

I examine mana and pule through the lens of what Michael Lambek calls 'ordinary ethics' to explore how claiming divine pule and mana is a strategic and ordinary way to deflect individual agency. Focusing on "ordinary" implies an ethics that is relatively tacit, grounded in agreement rather than rule, in practice rather than knowledge or belief and happening without calling undue attention to itself' (Lambek 2010: 2). Similarly, selfhood requires embodied and discursive labour that is often a tacit, taken-for-granted, orientational process (Csordas 1994: ix) and an embodied and historically situated practical knowledge (Battaglia 1995: 3). Manifesting mana, and its pair pule, are discursive tools of everyday ethical practice that enable believers to speak and act with culturally recognised authority. Claiming divine authority and channelling divine power through the self are everyday ways that Pentecostal Christians in Samoa carve out distinct (i.e. different from mainline Christianity) and ethical ways of generating power in ways that are legible and valued across Christianities.

Mana and pule are evidence of the extraordinary qualities of God, and channelled into everyday life events that are also extraordinaryhealing, sickness-yet Pentecostal Christians are taught to tend to mana and pule in ways that are supposed to be ordinary and available to every born-again believer. As the preacher noted at the beginning of this chapter, 'Remember our church is a Pentecostal church'; Pentecostal Christians are encouraged to see their connection to the Holy Spirit as something special to them but also something they should learn to take for granted. Thus in this case, the ordinary aspects of ethics point to an ideal way to relate to God and God's immanence, 
which in practice is often a 'precarious achievement' (Lempert 2013: 371). I draw on Michael Lempert's (2013) recognition that there is a great deal of discursive and embodied labour involved in ethical practice. As such, I trace how in claiming pule and harnessing mana these practices are a way to negotiate tensions surrounding individual agency. While claiming pule and channelling mana ought to be ordinary and taken for granted, my interlocutors 'strain[ed] to make the ethical not just effective but intersubjectively evident' (Lempert 2013: 371). In other words, claiming pule and manifesting mana are discursive ways of deflecting individual agency in order to bring ethical personhood into being.

To develop this argument, I focus on how claiming pule and harnessing mana are basic skills taught in sermons and practiced in healing prayers. In the first section of this chapter I present excerpts from sermons at a Pentecostal church to analyse how Pentecostal Christians are taught to manifest mana in their own lives through the everyday practices of prayer and fasting. These sermons show how Pentecostal Christians are explicitly taught what ought to be taken-for-granted and ordinary. In the second section, I analyse how healing leaders carefully proclaim the pule of God as a way to explicitly harness the mana of God. This section shows the discursive labour involved in authorising individuals as agents of God. Together, these two sections show how through practice Pentecostal Christians bring mana into being through cultivating and representing a direct and personal relationship with the divine. In the third section, I briefly present the wider context of anthropological investigations on self-making in Samoa to argue that by articulating a relationship between mana and pule, Pentecostal Christians de-centre individual agency while revealing the divine as the source of efficacious action. I trace the ways that born-again Christians are encouraged to harness divine power through ethical self-making, which in turn helps to shape a social world that is suspicious of individual (and non-ranked) authority.

\section{Background}

Samoa is marked as a Christian nation - the oft-sighted motto of Samoa is 'Fa'avae i le Atua Samoa' ('Samoa is founded on God'). Christianity is embedded in Samoan hierarchies, as matai (titled chiefs) are often 
the elders or deacons of mainline congregations. Church institutions reflect missionisation strategies, which privileged local autonomy and Samoan strategies of accepting Christianity in ways that served local hierarchies and rivalries. Cluny Macpherson and La'avasa Macpherson write, 'The church is not seen as having inserted itself in and dominating Samoan custom. It is seen rather as something that Samoans inserted into the Samoan hierarchy in ways that ensured they maintained control of both institution and hierarchy' (Macpherson and Macpherson 2009: 108). The original missionary churches, now mainline churches, including Congregational, Methodist and Catholic, maintain the majority of adherents. The Congregational Christian Church Samoa (n.d.) reports having 192 churches and, according to the 2011 Census (Samoan Bureau of Statistics 2012), 51,131 members or 31.8 per cent of the population over age five. ${ }^{2}$ The World Council of Churches reports that the Methodist church in Samoa has a membership of 35,983 and 279 pastors (World Council of Churches n.d.); the 2011 census recorded membership to be 22,079 (Samoan Bureau of Statistics 2012). The 2011 census recorded Catholic membership to be 31,221 or 19.4 per cent of the population (Samoan Bureau of Statistics 2012).

Evangelical churches are marked as lotu fou (new churches) or lotu patipati (clapping churches), referring to the worship style. The first evangelical churches arrived in both Samoa and American Samoa in the 1950s (Ernst 2012). The most prominent of the evangelical churches is the Assemblies of God (AOG). By the 1970s, AOG churches began to grow rapidly and by 2002 there were 64 churches (Ernst 2012; Pagaialii 2006, 2012). The AOG reports having three Bible schools, 108 pastors, and 18,000 adherents (World Assemblies of God Fellowship, 2010). The 2011 census recorded AOG membership to be 12,868 or 8 per cent of the population (Samoan Bureau of Statistics 2012). There are several evangelical churches local to Samoa, including Worship Center and Peace Chapel, as well as others that originate elsewhere, including the Church of the Nazarene and Open Brethren (Figure 20). Membership for these churches is difficult to assess because the 2011 census includes all these evangelical churches as 'other'.

2 The total Samoan population is just under 190,000 and the population over age five is approximately 160,000 . 


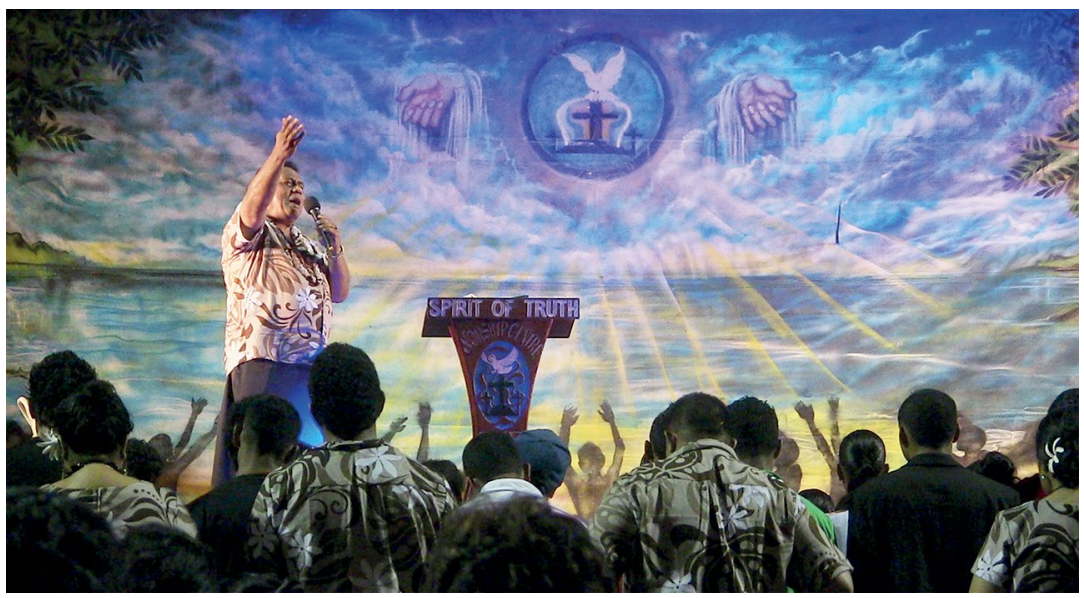

Figure 20. A pastor from Glory House preaches at a tent revival in Apia, 2012.

Source: Photograph by Jessica Hardin.

What is apparent from the census data, however, is that membership for mainline churches (Congregational, Methodist, Catholic) is slowly declining while membership in evangelical churches and other lotu fou (The Church of Jesus Christ of Latter-Day Saints (LDS), Jehovah's Witnesses, Seventh-day Adventists) is slowly increasing (see Samoan Bureau of Statistics 2012 for comparative data from 1981 through 2011). The slow exodus from mainline churches to evangelical churches is usually explained by two factors: changed worship styles and giving practices (Thornton et al. 2010; Besnier 2011; Macpherson and Macpherson 2011). ${ }^{3}$ Despite the growth of Pentecostal churches, leaving mainline churches for Pentecostal churches is difficult because, as many of my interlocutors have said, 'if you leave the [family] church, you leave the family'. Additionally, the centrality of (mainline) Christianity to everyday life in Samoa cannot be overstated: morning prayers in government ministries are common, and each evening across Samoa families gather for the sa (literally, 'sacred'),

3 Mainline churches practice public gift-giving while Pentecostal churches practice private tithing. The demands of mainline church giving are rigorous as congregants express their commitments to their family and village through the public display of gifts to pastors and the church. Tithing, on the other hand, is private and calculated based on income (10 per cent of income). 
which is a time when families gather to say evening prayers. Tracing how pule and mana are invoked illuminates some of the ways that interdenominational difference is managed in everyday life.

\section{Data and methods}

The data for this paper was collected during 14 months of ethnographic fieldwork in independent Samoa in 2011-12. Data is from church services, evangelising healing work at the national hospital, and prayers in a health clinic (Figure 21). I worked in two primary church fieldsites, the first an Assemblies of God church community in a periurban village and the second a Samoan-founded Pentecostal church in the urban area of Apia. During this time I audio and video recorded sermons, healing services, household prayers, and Bible study meetings. Over the course of fieldwork I worked with 10 research assistants transcribing and translating all the data presented here. The data selected for this chapter was then back-translated by one research assistant.

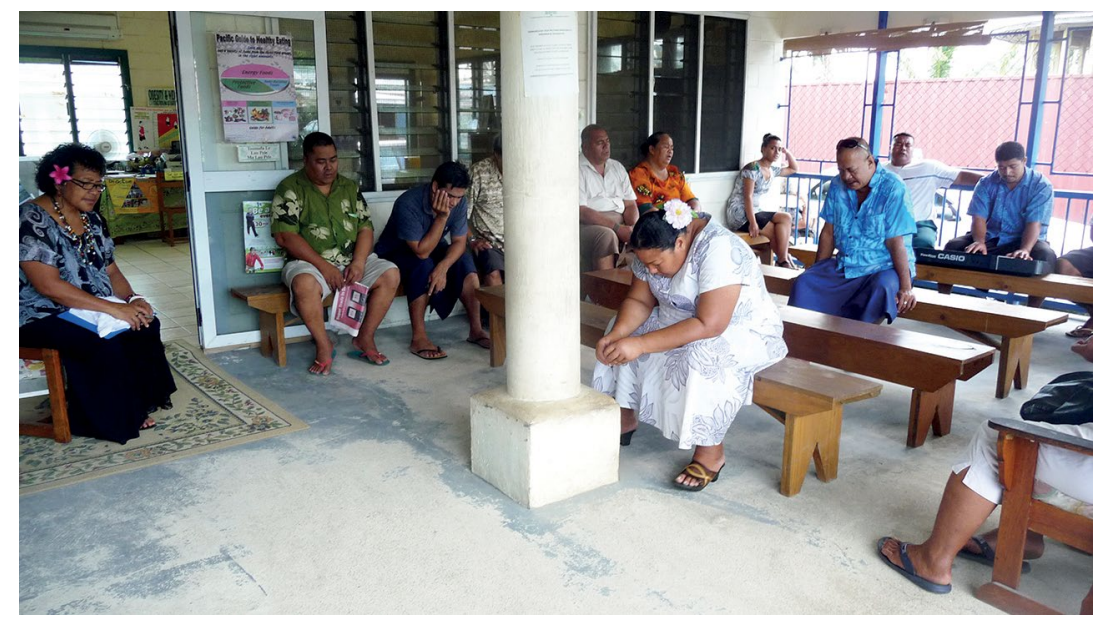

Figure 21. Morning prayers at a clinic, 2012.

Source: Photograph by Jessica Hardin.

I also participated in and observed at a diabetes clinic where I audio and video recorded morning prayers. Every morning at the clinic, the head nurse, who was also a Pentecostal pastor's wife, would ask the eldest man present to lead a prayer before clinical services began for 
the day. These prayers varied from brief prayers lasting a few minutes to prayers lasting up to 20 minutes. Prayers were always followed by a song. The head nurse, indexing her born-again Christianity, would end the morning prayers by saying in English, 'To God be the glory forever and ever, amen', while pumping her fist in the air. After the prayers I would ask the supplicant his denomination and also others in the clinic to learn perceptions about prayer styles and formulas. I only include prayers identified as lotu fou. The other main source of data I draw from is healing prayers among a group of female healers from an institution I call Glory House. The healing team have been evangelising during visiting hours in the hospital in Apia for over two years. They work in pairs. Some are pairs of more senior women with novices and others are teams that have been working together for long stretches of time; each has their own style developed over time through mentorship. These pairs approach women and men, young and old, and in most cases they do not know the denomination of the sick person and her family. Sometimes sick persons looked away to indicate they were not interested in interacting while others eagerly invited the pair over to their beds.

In order to understand pule and mana as concepts operating in everyday life rather than theoretical or philosophical abstractions, I searched all of my transcriptions for 'mana' and 'pule'. The data set included in this chapter is comprised of the 43 transcripts (out of 63) in which I found 'mana', 'pule', or both.

\section{The twins: Prayer and fasting}

While scholars are increasingly investigating prayer (Corwin 2012; Luhrmann 2012), fasting has received little attention (Hardin 2013). Prayer is 'a discursive act that bridges human limitation and the spiritual realm' (Baquedano-Lopez 2000: 197). Fasting is an embodied act that seeks to make the same connection. In Samoa, however, among evangelical Christians, prayer or fasting alone are not considered efficacious ways of bringing God's power into everyday life but must be co-practiced. Alo, an AOG preacher in his 50s, started his sermon by saying, 'Bible scholars say that prayer and fasting are brothers, or twins. They work together. They are of one heart' (3 November 2011). 'Twins' refers to the complementary linguistic and embodied labour 
involved in harnessing mana. Through sermons, Pentecostal Christians are trained to understand their prayer and fasting practices as essential to channelling divine mana and the blessings that accompany it. They learn to embed these practices in everyday life so they become taken for granted.

Alo said that 'God's pule over the world' begins with 'the individual spiritual life' (3 November 2011). He emphasised that individual embodied and discursive practices bring God's pule into being. Through these practices believers allow the divine to 'pour His mana and pulea [govern] the people who believe in God'. Believers' practices of prayer and fasting are intended to create a world governed by the divine. In turn, mana will manifest blessings in everyday life. He continued:

Fa'atumu, e fa'afou, o uiga nei o le upu fa'aolaolaina. $\mathrm{O}$ le toe fa' amalosia o 'oe ma $a^{\prime} u$, toe fa' afou 'oe ma a'u, toe fa'atumu 'oe ma a'u. Fa'atumu i le a? Ia toe fa'atumu i le mana o le Agaga Pa'ia. A fai tatou galuega, ole'a ia fa'amalosi ia tatou. Na te toe fa'atumu tatou. Ole'a toe sau e fa' afou ma fa'a'atoa i tatou. Ole'a toe sau e fa'atumu le tatou malosi. O le aso lenei olo'o tatou anapogi ma tatalo. Olo'o tatou vala'au i le mana ia afio mai i lalo e toe fa' afou tatou olaga. O lou tatalo ma lou anapogi ole'a tali mai e le Atua. Tatou te tilotilo i lona tali fa' aāliali mai. E fa'aaliali mai ana galuega ona o le mana lea. E va'aia i le autalavou, i tatou tina, i tatou tama. $\mathrm{O}$ le mana lea e fa'afouina ma fa'atumuina le fa'apotopotoga.
Refill, to renew, these are the meanings of revival. To restrengthen you and me, to renew you and me, to refill you and me. Refill with what? To be refilled with the mana of the Holy Spirit. When we do work, He will strengthen us. He will refill us. He will come to renew and complete us. He will come to refill our strength. This day we are fasting and praying. We are asking the mana to come down and to renew our life. Your prayer and your fasting will be answered by God. We look at His obvious response. It is obvious in His work because of this mana. It is seen in our youth, in our mothers, in our fathers. This mana it renews and refills the congregation. 
This message was met with enthusiastic responses of 'hallelujah' and 'amene' (amen). Prayer and fasting are practices that are ways of seeking divine strength. Alo suggests symmetry between prayer and fasting and asking for divine mana when he says: 'This day we are fasting and praying. We are asking the mana to come down and to renew our life.' Everyday religious practice establishes the believer as a conduit of divine blessings, and permits communication of needs to which the divine will answer. Mana is the generative means through which needs and prayers are answered. In this case, Christians are taught how to bring the abundance of God's potential into their lives by connecting to the mana of God through prayer and fasting. These may be individually oriented activities and achievements but supplicants are meant to understand the good things in their lives as the result of God's mana, not individual effort ('We look at His obvious response. It is obvious in His work because of this mana. It is seen in our youth, in our mothers, in our fathers. This mana it renews and refills the congregation').

Mana thus also manifests community well-being. Alo finished his sermon by saying:

O lou fa'atuatua olo'o koneti

i le mana o le Atua, vavega e tutupu, o maumaga ua tele ua tutumu kapoti mea'ai, ua tumu lou ato tupe, ua fa'amaloloina lou tino. Fa'atafe atu au fa'amanuiaga ia i latou.
Your faith is connected to the mana of God, miracles happen, plantations are abundant, pantries are full, your wallet is full, your body is healed. Let your blessings flow to them.

Prayer and fasting establish a connection to the divine. Another preacher referred to this as a spiritual telephone. The connection, which requires faithfulness and dedication to mindful practice, enables the mana of God to flow, which remains inactivated without these practices (see also Oroi, this volume). Sermons are explicitly aimed at teaching Pentecostal Christians what ought to be taken for granted and specifically how to become an ethical self. Congregants are reassured that when flow is established, material, psychological and embodied needs are met. Combined prayer and fasting are thus a way of seeking divine power and its potential effect in the world. By focusing on individual practice, these sermons were a practical guide to bringing the mana of God into one's own life without the 
assistance of pastors. This is also a tacit way that born-again Christians critique mainline Christianity and the presumed authority of pastors over congregants (Handman 2015).

\section{'Your power continues to work in us': Claiming pule, manifesting mana}

Born-again Christians in Samoa bring pule and mana into being through their personal prayer and fasting practices. These embodied practices are aimed at creating a direct connection between believer and divine that funnels mana into everyday life. Discursively, born-again Christians also work to authorise themselves as vehicles of mana to act on behalf of others. This effort to harness mana reveals the discursive labour involved in addressing extraordinary circumstances through ordinary practices. Performatively claiming divine pule enables healing mana to manifest.

Anthropologists have long explored the performative force of language in evangelical Christian practice (Coleman 2000; Harding 1987). Pentecostal religious language, particularly when it comes to healing, privileges speech acts that transform bodies and worlds through their utterance (Austin 1962). Simon Coleman writes, 'Words come to create the very reality which they purport to describe' (2000: 131). Claiming healing, or speaking healing, brings it into being for Pentecostal Christians around the globe. There were two ways I observed claiming pule in order to bring healing mana into being: first, in clinic-based prayers where supplicants interceded on behalf of both sick persons and medical professionals asking for healing power to be channelled through medical interventions; second, in healing prayers performed in the hospital where female healers, who were also evangelising, would claim divine pule over the world and seek to act as agents of healing mana.

Claiming pule has the capacity to release mana to believers and medical practitioners. These prayers render the medical work about to take place at the clinic efficacious. Manu, a diabetes patient in his 60s, led the morning prayer at the clinic one morning, saying: 
Ole'a ou ta'ita'ia tatou i se tatalo. Sa matagi, ma malulu ma timu le aso lenei, 'ae o le matou mana' o aua o 'oe o le na faia, o le pule o ō matou olaga ma mea 'uma. O 'oe o le matou leoleo mamoe e gaioi. E te le moe. Matou te fa' afetai mo lenei aso ua e aumaia. Matou te le faitio auā o 'oe olo'o iai le pule o o matou olaga aua e leai se matou malosi. O matou olaga olo'o i ou 'a'ao. O 'oe o le Atua soifua. Le Atua, matou te vaala' au ia oe ia fa' asusulu mai lou alofa i luga ia te'i matou nei ua potopoto i lenei fale. O matou tama, o matou tina, matou te si'itia atu ia te oe e auala i lima o foma'i ma teine tausi ma'i olo'o fesoasoani ia te'i latou ia toe malolosi. Fa'amanuia ia te'i latou uma. Matou te manatua lenei fa'apotopotoga ina ia iai lou mana fa'amalolo i luga o i latou e ala i vai ua saunia. (19 January 2012)
I will lead us with a prayer. It's been windy and cold and rainy this day, but it's our wish because you are the creator, the pule (ruler) of our lives and everything. You are our active shepherd. You never sleep. We thank you for this day you have brought, we don't have to complain because you have the pule for our lives because we don't have the strength. Our lives are in your hands. You are the living God. God we call on you to shine your love upon us who are gathered here in this house. Our fathers and our mothers, we carry them to you through the hands of doctors and nurses who are helping them get better. Bless all of them. We remember the ministry that your healing mana will be upon them through the medicine they have prepared.

Tasi, another diabetes patient who was in his 60s, began his prayer by saying:

E fia momoli atu le agaga fa' afetai ia te oe ona o le ola ma le malosi i tama ma tina matutua ua matou fa' atasi ai i lenei itula. Le Atua, alofa mai ma fesoasoani i foma'i i le fa'atinoina o latou tiute ina ia iai le mana o ou fa'amanuiaga ia i latou. Ia iai le malamalama i le fa'atinoina o latou tiute a'o matou ōmai mātou te mo'omia se fesoasoani. (12 January 2012)
We would like to give our thankful hearts to you for the life and the strength to the old fathers and mothers. We are together this hour. God, love us and help the doctors with their duties so the mana of your blessings comes to them. Let them have understanding for their duties as we come wanting to get some help. 
Recognising authority in order for mana to be released is a dynamic performative interaction. In each example, the supplicant begins by claiming divine authority over the world ('You are the creator, the pule (ruler) of our lives and everything', or 'We would like to give our thankful hearts to you for the life'). God is represented as all-powerful and omnipresent ('We thank you for this day you have brought, we don't have to complain because you have the pule for our lives because we don't have the strength'). Supplicants also represent themselves as powerless and dependent upon that animating authority for strength ('Our fathers and our mothers, we carry them to you through the hands of doctors and nurses who are helping them get better' and 'Let them have understanding for their duties as we come wanting to get some help'). By claiming divine pule and recognising the limitations of humanity, supplicants positioned themselves as seekers. In seeking and appropriately asking for divine mana, individual believers could channel that mana. Mana is channelled into medicines and doctors so that both objects and persons may be efficacious in their healing capacities.

Prayers are structured in such a way so as to create a world of divine authority over the lives of supplicants, and the nation of Samoa, in order to ask for healing power. Mana is power that is derived from appropriate divine authority and then channelled through, in this case, physicians and nurses to administer their medications. Physicians, nurses and medications are efficacious because the world is orchestrated in the appropriate fashion: divine authority is the source of all blessings; healing power is channelled to those with knowledge who act as conduits for efficacious healing. Through the performance of prayer an ideal cosmic order is established, which in turn enables divine intervention.

Patients authorise medical practitioners and imbue their work with efficacy in clinic prayers. Conversely, hospital-based healers must actively authorise themselves as efficacious healers; this is a difficult process in Samoa when healers do not have the usual trappings of authority, including titles, wealth or education. On their weekly visits to the hospital, the healing team often began with a conversation about the sicknesses facing the patient and then switched to evangelising. If the patient agreed to say a salvation prayer, which was often quick and formulaic, the ministry team members would either perform deliverance and healing or only a healing prayer. Before even entering the hospital the ministry team would pray. The prayers were led by the ministry team leader, Hana, and they were often also short and formulaic. 
Matou te vala'au i lau pule ina ia e fesoasoani mai ia matou. $\mathrm{O}$ au galuega le Atua, matou te mo'omia lau fa'au'uga mana. Ia e alofa i le matou vaega i le mana o lou Agaga Paia i lenei taeao. (8 May 2012)

Matou te vala'au atu mo le mana o lou agaga. O lau fanau lea ole'a galulue i le falema'i i le aso. Matou te vala'au i le mana o lou Agaga e foa'i le matou fesoasoani sili. Lo matou faia'oga fa'amolemole afio mai e fa'amatala o matou gutu ina ia tautatala o matou laugutu, tatala o matou loto ina ia mafai ona matou momoli lau upu i totonu o si matou atunu'u pele o Samoa. Ia iai lau mana i totonu o i matou uma i lenei falema'i ina ia tatala taliga o lou atunu'u aua lau Upu olo'o laugaina e au 'au'auna i le aso. Ia iai 'oe ma i matou ma ia e fesoasoani mai Agaga Paia i lau fanau, ma ia fa' afoi atu le vi'iga ia te 'oe. (5 June 2012)
We call upon your pule so that you can help us. Your works God, we need your holy anointing, have mercy on our team through the mana of your Holy Spirit this morning.

We ask you for the mana of your spirit. Your children will be working in the hospital today. We ask for the mana of your spirit to give our best help. Our teacher please come to open our mouths and let our lips speak, open our hearts so we can deliver your Word inside our dear country Samoa. Let your mana be with all of us in the hospital to open the ears of your country in order for your Word, that is delivered by your servants this day, to fit. Be with us Father and may your Holy Spirit be with your children and we should return the praising back to you.

In both examples mana animates: it opens ears, minds and mouths to be efficacious in the delivery of a divine message or reception of such a message. Through their prayers the healers establish divine pule in order to render themselves efficacious conduits for divine healing mana. In claiming divine pule, individual agency is backgrounded while individuals and objects (supplicants, medical practitioners, medicines) become the conduits of divine mana. Efficacy is centred in the ability both to channel divine healing power and to speak effectively so as to affect potential believers, to make them effective message-bearers. 
Before the hospital visits, the women in the healing team would often discuss how entering the hospital was difficult. Speaking to strangers and experiencing the potential antagonism of interdenominational differences was difficult and sometimes painful. The prayers quoted above were one way the group performatively constituted themselves as effective and authoritative actors. In this example, mana works materially through the imagery of the blood of Jesus. Louisa, one of the senior members of the healing team, prayed over a patient in the hospital who was suffering from stomach pain:

Le Atua, Tama, tatala o matou loto ina ia fa'alogo i lau Upu, le Upu o le ola. Matou te vala'au atu ia oe i lenei itula, ia fufuluina i matou e le mana o le toto o Iesu mai o matou ulu se'ia o'o i o matou tamatama'i vae. Fufulu o matou loto e fa'alogo. Tama, ia e fa'amanuia i o matou uso, matou te vala'au atu i lenei taeao e leai se mea e te le mafaia. E alu lau upu ma le mana ia te i lātou. Matou te avatu le fa'afetai ma vala'au atu ia e suia o latou loto. Matou te fa' afetai ona ua e tusia o latou loto i le tusi o le ola. Tama, $\mathrm{O}$ oe ua iai le pule. E te silafia mea uma mai le ulu se'ia o'o i vae. Oute vala' au atu ia 'oe Tama e te afio i totonu o le manava i le mea olo'o iai le fa'afitauli. Tama matou te vala'au atu ia 'oe, i le mana o lou toto ia 'a'apa atu i o matou uso. Lo matou Tama, matou te vala'au atu ia 'oe, e leai se mea e faigata ia 'oe. Ua ia'i matou le pule ma le mana e fa'aleagaina ai ma'i. Matou te tutu i le pule ma le mana ua e aumaia e fa'aleaogaina ai le suka. (21 February 2012)
God, Father, open our hearts to listen to your word, the Word of life. We call you this hour, let the mana of your blood Jesus clean us from our heads to our toes. Clean our hearts to listen. Father bless our brother, we call this morning Father because there is nothing you can't do. Your Word goes with the mana to them. We give you thanks and ask you to change their souls. We give thanks that their souls are written in the book of life. Father, you have the pule. You know everything from the head to the toe. I ask you Father to go inside the stomach where there's a problem. Father we call you, the mana of your blood to reach our brother. My father, we call you. Nothing is impossible for you. We have the pule and the mana with us to destroy this sickness. We stand and believe in the pule and mana you gave us to destroy the sugar. 
In this example, Louisa claims divine authority and asks that God heal inside the body. The blood of Jesus Christ is thought to be the material of mana, that which covers bodies and protects them or that which heals bodies. Pule here is associated with divine omniscience and healing is a process of recognising that omniscience and human inadequacy. As conduits for divine mana, though, healers direct the potentiality of this healing power. By extension healers have access to divine authority and towards the end of the excerpt above, Louisa indicates a switch from directing the divine, 'You have the pule', to a collective 'we' who as healers manifest divine mana: 'We have the pule and mana with us.' Claiming pule and invoking the blood of Jesus Christ, these healers instantiate what is referred to as the believer's authority. This healing prayer also brought a newly born-again person into a community of believers with the deictic marker 'we' by extending this authorisation and animating power into each believer. By sharing this authority with the whole group, healers worked against the imperative of mainline Christian hierarchical authority where divinely originated authority and power are thought to rest in pastors and matai only.

Through the performative forces of language, and as a result of healers' harnessing of mana, efficacious healing is possible. These are not extraordinary prayers, although the circumstances are extraordinary, but are everyday embodied and discursive practices available to all believers to channel and direct divine mana. These methods reveal the ways that mana is harnessed with care, revealing the effort involved in acting appropriately, and therefore ethically, in interdenominationally diverse contexts.

\section{De-centring agency and self-making}

Scholars of Christianity in the Pacific have recognised a basic tension between Christianity and indigenous orientations towards ideas about the individual (see Robbins 2004; Keane 2007). Christian practices are associated with cultivating individual subjectivity, responsibility, and, for evangelical Christians, a personal relationship with God. This contrasts with the ways that most societies in the Pacific tend to 'de-emphasize individualism' (Tomlinson 2011: 155). In Samoa, Bradd Shore (1982) suggests a concept of self with multiple sides, as opposed 
to an imagined western self that is cohesive and acontextual. 'Lacking any epistemological bias that would lead them to focus on "things in themselves" or the essential qualities of experiences', Shore writes, 'Samoans instead focus on things in their relationships, and the contextual grounding of experience' (1982: 136). Selfhood can be considered a way of enacting the well-known Samoan expression teu le va (taking care of the relationship) (Lilomaiava-Doktor 2009, Ka'ili 2005). Albert Wendt writes, 'Important to the Samoan view of reality is the concept of $\mathrm{Va} . \mathrm{Va}$ is the space between, the betweenness, not empty space, not space that separates, but space that relates' (Wendt 1999: 402). Taking care of the $v a$ then is an expression that highlights how Samoans 'value group unity more than individualism' (Wendt 1999: 402). Alessandro Duranti also writes that Samoans privilege social context in determining self-identity and action and suggests that Samoans are not concerned with knowing intentions but with 'the implications of the speaker's actions/words for the web of relationships in which his [sic] life is woven' (1992: 42). It can be argued then that agency is not located within the individual to act based on emotion, motivation, or intention but 'Samoan behavior is (externally) "caused"' (Shore 1982: 136). In other words, context drives the particular aspects of self that are highlighted or inform action in any given moment. Again, Shore writes, 'This Samoan emphasis on correct perception of social relations and their requirements goes far beyond a concern for etiquette or tact. It is a moral and epistemological axiom' (1982: 137). Perception of social relations is a moral and epistemological axiom because it informs how one will self-identify and self-present, which informs how one will act. Here I briefly explore anthropological approaches to selfhood in Samoa because when pule and mana are invoked they mediate the tensions of Samoan orientations towards a flexible selfhood informed by social relations-in-context and the Christian imperative for faith and Christian action that is individual and consistent across contexts.

As part of Christian self-making practice, claiming pule and invoking mana reflect a cultural and social context that is skeptical of individual intentional action. Among evangelical Christians, taking credit for healing or demonstrating pride in one's spiritual work is looked down upon and actively avoided. Generally in Samoa, as Ilana Gershon recognises, pride is 'one of a small number of motivations' Samoans attribute to one another (Gershon 2012: 56). Accusations of fiapoto 
or fiamaualuga are in constant circulation. These accusations suggest arrogance and incompetence about appropriate matching of behaviour with social expectations (see Gershon 2012: 146). Fears of these accusations are apparent in Pentecostal Christian spiritual practice where individuals are accused of identifying healing efficacy with the healer and not God. Consistently invoking pule and mana is one way that individual agency is deflected but not rendered invisible. Deflecting individual agency is thus one way to bring ethical selfhood into being, but it requires discursive labour.

Hirokazu Miyazaki argues that Christian faith in Fiji emerges as the 'capacity to place one's agency in abeyance' (2000: 32). Claiming pule and channelling mana work in a similar way, as Pentecostal Samoans de-centre individual agency while foregrounding divine agency. In these cases the efficacy of individuals and groups is not hidden but only represented as a shadow of the real source: God's mana. Individual agency is de-centred when supplicants bring attention to the inefficacy of their own action without divine mana. Sam, a diabetes patient in his 60s, led the morning prayer by saying:

Le Atua lo matou Tama, matou te 'avatu lenei taeao, e pei ona e taga'i mai ua matou omai ma o matou ma'i ia 'oe. O 'oe 'olo'o iai le Pule, ioe Tama, o 'oe olo'o iai le Pule, i mea 'uma. O foma'i olo'o iai le poto i o latou tiute, ae a leai lou mana, ma au vavega e leai se mea e mafai ona matou faia. O le matou tatalo lena ia 'oe lo matou Tama, alofa Tama fesoasoani mai ia matou. Ia aoga latou vai ma togafitiga, ina ia fa' aali mai ai lou mana ina ia matou maua ai lau fa'amalologa mai ia oe. (17 February 2012)
God our Father, we give you this morning as you can see that we are coming with our sicknesses to you. You have the pule, yes Father you have the pule, over everything. The doctors have their wisdom and their duties, but without your mana, and your miracles there's nothing we can do. That is our prayer to you our Father, loving Father help us. May their medicines and their treatments be useful, in order to show us your mana in order for us to receive healing from you.

God's authority is established here, and doctors are represented as having wisdom. However, wisdom alone cannot bring about healing, animating mana is required. Prayers are thus the means of activating 
that efficacious power. This is also expressed by the healing team, who also prayed together as a group after leaving the healing ministry. Hana said:

Fa' afetai mo le fa'ataunu' uina o lau upu i loto ma mafaufauga o lau fanau a'o asiasi mai i le falema'i i le aso. E tatau ona matou fa'afetai ia oe ona o le 'au'aunaga a au 'au'auna fa'atauva'a aua e leai se mea matou te mafaia pe a aunoa ma lou mana. Fa' afetai Tama, matou te vala'au atu ia e fa'amagalo ia matou vaivaiga ma agasala i le mana o lou toto Iesu. Ia e foai mea e mo'omia e i mātou ta'ito'atasi, i lona lava loto le Atua ia e foa'i. (5 June 2012)
Thank you for keeping the words in the hearts and the thoughts of your children as they visited the hospital today. We should thank you for the humble service of your servants, because there's nothing we can do without your mana. Thank you Father, we ask you to forgive us for our weaknesses and our wrongdoings with the mana of your blood Jesus. Let you Lord meet all the needs of each person, her own heart may you Lord meet it.

Here Hana said bluntly: 'There's nothing we can do without your mana.' Both examples demonstrate how supplicants, physicians and healers are ineffective without divine mana. Mana is positioned as the source of efficacious action, which requires recognition and appropriate ways of relating to that source. Speaking of ineffectiveness is essential to bringing about effective action.

Mana also creates futures for individual persons that imbue the life course with efficacy to fight against evil in everyday life. At times beyond the recognition of individuals, mana is the material of the divine within the person to act in a divinely orchestrated plan. The following examples are taken from closing prayers of the healing team. Hana led both prayers: 
E tatau ona tatou tau fa' asaga i le ti'apolo o lenei lalolagi olo'o taumafai e fa'asalavei i le fa'atinoina o lau vala'auga. Ua e vala'auina i matou. E pei ona e fetalai ia matou tutū i luga ma e, matou te talitonu o lou mana e fa'aauauina le galuega i totonu ia'i matou ma ole'a iai le taimi i le lumana'i ole'a mātou saunia lelei ai o ni au fanau. Ona matou o'o atu lea i le isi tulaga ma va'ai i lou mataoutia, ma au faoamanuiaga ona o lau valaoauga ia'i matou. (15 May 2012)

Aumai ia te'i matou le malosi i totonu o matou aiga matou te alolofa ai ia'i latou ma i latou e pele ia te'i matou, tusa pe olo'o iai le fa'anoanoa ona latou te le iloa oe Tama. Silasila mai ia'i matou i le alofa, o lau fanau, fa' afaigofieina e lou malamalama ma lou mana ona 'a'apa atu i o matou aiga ina ia latou iloa mea moni ia e fa'aalia i o matou loto, aua o le mea lea na e vala'auina ai i matou ina ia mafai ona latou mulimuli i lea fa'ata'ita'iga. (15 May 2012)
We need to fight against the devil of this world who tries to get in the way of your calling, you have called us. Just like you have spoken to us rise up and go forth, we believe that your mana continues to work in us and that there will be a time in the future when we will be well-prepared as your children. Then we will reach another level and see the wonders of you and the blessings of being called by you.

Give us the strength in our families for us to love them and all those that are dear to us even if it's with sadness to know that they do not know you Father. Look upon us with love, your children, make it easy for your light and your mana reach into our families so that they may come to know the truth that you have revealed to our hearts, which is why you have called us so that they may be able to follow this example.

Mana works in the moment it is claimed, as with the medicines of doctors, but it can also set into motion a divine plan. In each of these examples, mana is not only credited for past effective action but also sets forth a future of effective action. Mana then has the capacity to propel healers into the future not only as they heal in the hospital but as they evangelise in their own families. In this way, mana enhances self-efficacy in difficult contexts of interdenominational kinship. Managing pule and mana in prayer and fasting form a set of discursive and embodied practices that highlight how to maintain 
ethical individual relations with the divine. Through these takenfor-granted practices, individual supplicants represent themselves as powerless without the animating capacity of mana. In revealing human inefficacy, ethical practice is brought into being.

\section{Conclusion}

For Pentecostal Christians, mana must be carefully brought into being through specific practices, including prayer, fasting and specific linguistic handling of pule and mana. In this process divine agency is recognised, which in turn animates human capacities. De-centring human agency is important to maintaining the divine as source and also circumspectly managing a Samoan prejudice against individually mandated authority. De-centring human agency does not render invisible human agency but instead indicates appropriate and ethical ways of acting. Louisa shared with me that when she was first born again, she kept receiving a single word message from God. Like a highlighted word on a computer screen, she recounted, YIELD flashed as she prayed, as she dreamed, and as her mind wandered during the day. Surrendering to divine agency then is an active and ethical human capacity in relation to which divine mana is enabled, requiring embodied and discursive labour.

Harnessing mana, according to Pentecostal Christians, is available to all born-again believers. This is an instance of the ways Christianity 'as an institutional force' has 'created [a] new sense of mana' (Tomlinson 2006: 182). Claiming pule and harnessing mana mediate the widely recognised tension between a relational model of Samoan selfhood over that of an individually driven model of self, which Christian practice aims to cultivate (see Tomlinson 2011; cf. Schram 2013). In a resonant comparative example from Papua New Guinea, Joel Robbins (2004) argues that the dyad of sin and salvation mediate Urapmin tensions between individual and relational notions of self. In particular, 'spirit disko' rituals are instances where Urapmin work to cultivate collective salvation while in everyday life they focus on monitoring individual sin. In these rituals of redemption, 'indigenous and Christian understandings [are] working in concert rather than at cross-purpose' (2004: 287). 
Individuals from across station and rank in Samoan society may harness mana and its animating capacities through practice and language, not through conferral of title by family. Mana mediates the tension between the ideal individual agentive Christian believer and Samoan orientations towards prioritising relationships and context over individual intention by rendering individuals' effectiveness dependent upon divine power. By claiming pule and channelling mana, Pentecostal Christians create the possibility for effective action by foregrounding the divine as source for current and future action. In this process, individual agency recedes but does not disappear. This de-centring of agency permits recognition of individual work only insofar as this work is appropriately linked to the animating mana. Claiming pule and harnessing mana are thus part and parcel of developing an ethical Samoan Christian self.

'Everything is possible through the mana of God', Louisa said to me as we walked out of the intensive care unit after praying over a woman dying as a result of complications arising from a stroke. 'We can do nothing without Him', she said sadly as she comforted the sister of the dying woman (5 March 2012). Whispered to comfort, and repeated in prayer, sermons, and elsewhere in everyday life, the divine is the source of mana. All born-again Christians have this ordinary capacity, which they heighten through prayer, fasting, and their authorising uses of pule and mana. When born-again Christians recognise their own authority and capacity to connect with the divine, they challenge mainline Christianity in Samoa which centres the priest or minister as the divine conduit between God and congregants. Claiming pule and channelling mana is thus one way that born-again Christians in Samoa bypass hierarchies in mainstream Christianity. Not only do bornagain Christians in Samoa personalise faith and a relationship with the divine but they teach believers how to manifest divine power in their everyday lives.

\section{Acknowledgements}

This research was funded by a Wenner Gren Dissertation Grant. I would like to thank the staff at the clinic where I recorded for their generosity and patience with me. Many thanks to Christina Kwauk for her comments on an earlier draft and to Mafiosamoa Palepoi for 
her help with translations. Finally, I am grateful to Matt Tomlinson and Ty Kāwika Tengan for their generous feedback throughout the writing of this chapter.

\section{References}

Anae, Melani. 1998. Fofoa i Vaoese: Identity journeys of New Zealandborn Samoans. PhD thesis, University of Auckland.

Austin, J.L. 1962. How to Do Things with Words: The William James Lectures Delivered at Harvard University in 1955, ed. J.O. Urmson and Marina Sbisà. Oxford: Clarendon Press.

Baquedano-Lopez, Patricia. 2000. Prayer. Journal of Linguistic Anthropology 9(1-2): 197-200.

Battaglia, Debbora. 1995. Problematizing the self: A thematic introduction. In Rhetorics of Self-Making, ed. Debbora Battaglia, pp. 1-16. Berkeley: University of California Press.

Besnier, Niko. 2011. Reconfiguring the modern Christian. In On the Edge of the Global: Modern Anxieties in a Pacific Island Nation, pp. 205-30. Contemporary Issues in Asia and the Pacific Series. Stanford: Stanford University Press.

Coleman, Simon. 2000. The Globalization of Charismatic Christianity: Spreading the Gospel of Prosperity. Cambridge: Cambridge University Press.

Congregational Christian Church Samoa. n.d. Parishes. Online: www.cccs.org.ws/index.php (accessed 2 November 2015).

Corwin, Anna. 2012. Changing God, changing bodies: The impact of new prayer practices on elderly Catholic nuns' embodied experience. Ethos 40(4): 390-410.

Csordas, Thomas J. 1994. The Sacred Self: A Cultural Phenomenology of Charismatic Healing. Berkeley: University of California Press. 
Duranti, Alessandro. 1992. Intentions, self, and responsibility: An essay in Samoan ethnopragmatics. In Responsibility and Evidence in Oral Discourse, ed. Jane H. Hill and Judith T. Irvine, pp. 24-47. Cambridge: Cambridge University Press.

Engelke, Matthew and Matt Tomlinson (eds). 2006. The Limits of Meaning: Case Studies in the Anthropology of Christianity. New York: Berghahn Books.

Eriksen, Annelin. 2014. Sarah's sinfulness: Egalitarianism, denied difference, and gender in Pentecostal Christianity. Current Anthropology 55(S10): S262-S270.

Ernst, Manfred. 2006. Samoa. In Globalization and the Re-Shaping of Christianity in the Pacific Islands, ed. Manfred Ernst, pp. 539-77. Suva: Pacific Theological College.

- 2012. Changing Christianity in Oceania: A regional overview. Archives de Sciences Sociales des Religions 157: 29-45.

Gershon, Ilana. 2006. Converting meanings and the meanings of conversion in Samoan moral economies. In The Limits of Meaning: Case Studies in the Anthropology of Christianity, ed. Matthew Engelke and Matt Tomlinson, pp. 147-64. New York: Berghahn Books.

- 2012. No Family Is an Island: Cultural Expertise among Samoans in Diaspora. Ithaca: Cornell University Press.

Handman, Courtney. 2015. Critical Christianity: Translation and Denominational Conflict in Papua New Guinea. Berkeley: University of California Press.

Hardin, Jessica A. 2013. Fasting for health, fasting for God: Samoan Evangelical Christian responses to obesity and chronic disease. In Reconstructing Obesity: The Measures of Meaning, the Meaning of Measures, ed. Megan McCullough and Jessica A. Hardin, pp. 107-30. New York: Berghahn Books.

Harding, Susan F. 1987. Convicted by the Holy Spirit: The rhetoric of fundamental Baptist conversion. American Ethnologist 14(1): 167-81. 
Henderson, April K. 2010. Gifted flows: Making space for a brand new beat. The Contemporary Pacific 22(2): 293-315.

Hereniko, Vilsoni and Rob Wilson (eds). 1999. Inside Out: Literature, Cultural Politics, and Identity in the New Pacific. Lanham, MD: Rowman \& Littlefield Publishers.

Hill, Jane H. and Judith T. Irvine (eds). 1992. Responsibility and Evidence in Oral Discourse. Cambridge: Cambridge University Press.

Howard, Alan and Robert Borofsky (eds). 1989. Developments in Polynesian Ethnology. Honolulu: University of Hawaii Press.

Ka'ili, Tevita O. 2005. Tauhu va: Nurturing Tongan sociospatial ties in Maui and beyond. The Contemporary Pacific 17: 83-114.

Kame'eleihiwa, Lilikalā. 1992. Native Land and Foreign Desires: Pehea Lā E Pono Ai? How Shall We Live in Harmony? Honolulu, HI: Bishop Museum Press.

Keane, Webb. 2007. Christian Moderns: Freedom and Fetish in the Mission Encounter. Berkeley: University of California Press.

Lambek, Michael, ed. 2010. Ordinary Ethics: Anthropology, Language, and Action. New York: Fordham University Press.

Lempert, Michael. 2013. No ordinary ethics. Anthropological Theory 13(4): 370-93.

Lilomaiava-Doktor, Sa'ilemanu. 2009. Beyond 'migration': Samoan population movement (malaga) and the geography of social space (va). The Contemporary Pacific 21(1): 1-32.

Luhrmann, T.M. 2012. When God Talks Back: Understanding the American Evangelical Relationship with God. New York: Knopf.

Macpherson, Cluny and La'avasa Macpherson. 2009. The Warm Winds of Change: Globalization in Contemporary Samoa. Auckland: Auckland University Press.

- 2011. Churches and the economy of Samoa. The Contemporary Pacific 23(2): 304-37.

Marshall, Wende Elizabeth. 2011. Potent Mana: Lessons in Healing and Power. Albany: State University of New York Press. 
McCullough, Megan and Jessica A. Hardin (eds). 2013. Reconstructing Obesity: The Measures of Meaning, the Meaning of Measures. New York: Berghahn Books.

Meleisea, Leasiolagi Malama. 1997. The Cambridge History of the Pacific Islanders. Cambridge: Cambridge University Press.

Miyazaki, Hirokazu. 2000. Faith and fulfillment: Agency, exchange, and the Fijian aesthetics of completion. American Ethnologist 27(1): 31-51.

Pagaialii, Tavita. 2006. Pentecost 'To the Uttermost': A History of the Assemblies of God in Samoa. Baguio City: Asia Pacific Theological Seminary Press.

Robbins, Joel. 2004. Becoming Sinners: Christianity and Moral Torment in a Papua New Guinea Society. Berkeley: University of California Press.

Salesa, Damon. 2011. Racial Crossings: Race, Intermarriage, and the Victorian British Empire. Oxford: Oxford University Press.

Samoan Bureau of Statistics. 2012. Population and Housing Census 2011. Apia, Samoa.

Schram, Ryan. 2013. One mind: Enacting the Christian congregation among the Auhelawa, Papua New Guinea. The Australian Journal of Anthropology 24: 30-47.

Shore, Bradd. 1982. Sala'ilua: A Samoan Mystery. New York: Columbia University Press.

- 1989. Mana and tapu. In Developments in Polynesian Ethnology, ed. Alan Howard and Robert Borofsky, pp. 137-73. Honolulu: University of Hawaii Press.

Silva, Kalena. 1997. The adoption of Christian prayer in Native Hawaiian pule. Pacific Studies 20(1): 89-99.

Tengan, Ty Kāwika, Tevita O. Ka'ili and Rochlle Tuitagava'a Fonoti. 2010. Genealogies: Articulating Indigenous anthropology in/of Oceania. Pacific Studies 33(2-3): 139-67. 
Thornton, Alec, Maria Kerslake and Tony Binns. 2010. Alienation and obligation: Religion and social change in Samoa. Asia Pacific Viewpoint 51(1): 1-16.

Tomlinson, Matt. 2006. Retheorizing mana: Bible translation and discourse of loss in Fiji. Oceania 76(2): 173-85.

- 2011. The true me: Individualism and Biblical types in Fijian Methodism. In Managing Modernity in the Western Pacific, ed. Mary Patterson and Martha Macintyre, pp. 147-71. St Lucia: University of Queensland Press.

Valeri, Valerio. 1985. Kingship and Sacrifice: Ritual and Society in Ancient Hawaii, trans. Paula Wissing. Chicago: University of Chicago Press.

Wendt, Albert. 1999. Afterword: Tatauing the post-colonial body. In Inside Out: Literature, Cultural Politics, and Identity in the New Pacific, ed. Vilsoni Hereniko and Rob Wilson, pp. 399-412. Lanham, MD: Rowman \& Littlefield Publishers.

World Assemblies of God. n.d. Samoa - Participating Member. Online: worldagfellowship.org/fellowship/countries/wagf-participatingmember-s-z/samoa-2/ (accessed 2 November 2015).

World Council of Churches: A Worldwide Fellowship of Churches Seeking Unity, a Common Witness and Christian Service. n.d. Methodist Church of Samoa. Online: www.oikoumene.org/en/member-churches/ methodist-church-of-samoa (accessed 20 October 2015). 
This text is taken from New Mana: Transformations of a Classic Concept in Pacific Languages and Cultures, edited by Matt Tomlinson and Ty P. Kāwika Tengan, published 2016 by ANU Press, The Australian National University, Canberra, Australia. 